\title{
Straddling between Different Worlds: Navigating Diverse Fieldwork Modes
}

Iqra Anugrah, Kyoto University

ABSTRACT Fieldwork often is seen as a challenging and misunderstood intellectual enterprise. Long perceived as the domain of the few, fieldwork and immersion continue to be the chosen methodological techniques for many political scientists. Focusing on my own fieldwork experience in Indonesia since 2015 as an early-career researcher, I discuss and reflect on three types of activities: (1) policy research, (2) dissertation research, and (3) activist work. In particular, I highlight fieldwork serendipities, fieldwork logistics, and my experience in gathering data and interacting with various interlocutors. It is hoped that this self-reflection will help readers to better understand the relationship between researchers and their interlocutors and collaborators, demystify the fieldwork process, and better prepare political scientists who use fieldwork in their research.

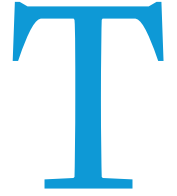

hat fieldwork is challenging and needs hands-on experience is well understood by political scientists. It is commonly heard that there is no specific course on how to conduct fieldwork in many political science departments, at least in the United States. This, in my view, is an accurate observation. Other than a staple menu of quantitative, qualitative, and philosophy of science methods courses, it may be difficult to name a methods course specifically dedicated to teach the know-how of fieldwork.

Such an image is understandable, given that fieldwork involves learning by doing, serendipities, and street-smart logistical preparation. Moreover, field researchers must test their research hypotheses against realities in the field. When combined, these two tasks present a significant challenge for both novice and seasoned fieldworkers. Far from being a linear process in which researchers magically discover "findings" in the field, fieldwork entails uncertainties and confusion pertaining to the technical and human-relations aspects of data collection and generalization.

This article describes possible strategies to navigate fieldwork in political science research based on my three years (i.e., mid2015 to mid-2017 and late 2018 to mid-2019) of in-country fieldwork experience as an early-career researcher studying Indonesian politics. Following previous scholars' work (Hsueh, Jensenius, and Newsome 2014; Soedirgo and Glas 2020), I reiterate the need for more reflexivity in fieldwork and political science research more generally.

Iqra Anugrah (1D) is a Japan Society for the Promotion of Science Postdoctoral Fellow at the Center for Southeast Asian Studies, Kyoto University. He can be reached at iqra@cseas. kyoto-u.ac.jp or officialiqraanugrah@gmail.com.
I share three reflections on my fieldwork experience. First, it pushed me to take advantage of serendipitous moments in the field and make sense of data obtained from different research sites while also ensuring that I had sufficient funding to conduct and finish my research. Second, when conducting my fieldwork, it was inevitable that I would need to negotiate various professional commitments and social relations with funders, other researchers, and local interlocutors. Third, I suggest several proposals to improve fieldwork practice, graduate-level education on fieldwork logistics, and working relationships with local collaborators and interlocutors.

\section{MODES AND STAGES OF FIELDWORK}

Key works on fieldwork extensively discuss the fundamentals of fieldwork and its potential contribution to the discipline (Aronoff and Kubik 2013; Fujii 2018; Schatz 2009; Simmons and Nicholas 2019; Yanow and Schwartz-Shea 2006). Although these accounts of field experience are appreciated, the discipline needs more conscious efforts to integrate self-reflection into its research process, especially because there is less flexibility in terms of financial support and time allocation for fieldwork compared to in the past. I believe my experience can shed light on ways to navigate different types of activities and actors while in the field.

The most intensive part of my research was between mid-2015 and mid-2017. For two years, I participated in activist work in different parts of Indonesia while also conducting fieldwork for my dissertation research and a collaborative policy-oriented research project on rural healthcare in Indonesia and Tanzania. This work was conducted under the auspices of the Transparency for Development $\left(\mathrm{T}_{4} \mathrm{D}\right)$ Predoctoral Fellowship of the Ash Center at the Kennedy School of Government at Harvard University and the Results for Development (R4D) Institute. 
Before this fieldwork, I had only little field experience: several short trips to rural areas in Indonesia during my student-activist phase-more specifically, from my teenage years to college. My $\mathrm{PhD}$ methods courses gave me some sensibility to the type of data that I had to gather. However, it was in the field that I learned to actually conduct research and other related activities-taking notes, obtaining contacts, socializing with my interlocutors, and delving into local newspaper and government archives while ensuring that I received sufficient research funds to extend my fieldwork and also do activist work. More than simply conducting the research project, fieldwork always entails a range of other activities, from taking a paid research project to subsidize living and research costs to keeping in touch with research supervisors stateside.

My fieldwork experience can be categorized in three activities: policy research, dissertation research, and activist work, all punctuated by dissertation writing from mid-2017 to mid-2018. Throughout my fieldwork beginning in 2015, I researched and wrote about various topics, from organized peasant groups and their activist allies (i.e., my core research and advocacy interest) to rural healthcare and environmental politics (i.e., my commissioned research topics). Although some areas among these research topics overlap, my involvement in these different projects necessitated different types of data-collection techniques, engagement with related stakeholders and interlocutors, and logistical preparation.

In my case, this strategy translates as follows. First, I used the paid, policy-oriented $\mathrm{T}_{4} \mathrm{D}$ fellowship to cover the logistics of my own research projects and living costs. Additionally, I applied for and fortunately received a small grant for Southeast Asian Studies research from the Institute of Thai Studies at Chulalongkorn University. Equally important, this financial support freed up my time, which allowed me to become involved in activist work such as giving lectures, co-organizing popular education sessions, and attending protests.

Second, whenever possible, I cross-fertilized my fieldwork activities: for example, using field notes on rural economy in $\mathrm{T}_{4} \mathrm{D}$ 's rural healthcare project as part of my $\mathrm{PhD}$ dissertation materials, maintaining friendships and collaborative working relationships with local agrarian and civil-society activists, and using my field experience to illustrate the challenge of day-to-day organizing and social-movement building in my lectures for student activists. This strategy allowed me to tackle multiple tasks more efficiently.

Eventually, these strategies paid off: I finished my $\mathrm{PhD}$, continued my collaboration with colleagues in the policy-oriented research project, and maintained my engagement in academia and the Indonesian social-movement landscape. However, my trajectory may not be typical, especially for graduate students from the Global South-many of whom begin their doctoral studies at an older age with spousal and parental obligations. Although my jobsearch experience was by no means easy, I was privileged to be employed post-PhD and had the rare opportunity to conduct additional fieldwork for my dissertation-based book project.

\section{THE DYNAMICS OF DATA GATHERING}

One of the most challenging tasks for me was maintaining balance between completing my paid research projects and gathering data for my dissertation and potential publications. Due to professional obligation, I had to prioritize my commissioned projects first. For example, in the first six months of my fieldwork, I mostly focused on finishing my ethnographic research for $\mathrm{T}_{4} \mathrm{D}$ 's rural healthcare research project; only afterwards could I concentrate on my own dissertation research. I experienced the same scenario in Indonesia after graduation when I was a research fellow with the Australian National University's New Mandala Indonesia Correspondent Fellowship from late 2018 to mid-2019: the professional obligation for my research fellowship came first, my book project second.

Fortunately, the close connection between these policyoriented studies and my own research agenda meant that I could manage both responsibilities more efficiently. The common thread that connected these professional research projects (i.e., on rural healthcare and environmental governance) and my own project (i.e., agrarian politics) was a focus on rural development. This allowed me to mention these research projects in conversations, thereby enriching the data-collection process for each study. For instance, I used data on the state of basic services in villages where I conducted the rural healthcare study in my dissertation and findings from my own research for empirical reference in my op-eds on environmental issues in Indonesian politics.

Another challenge was navigating between different research frameworks and methodological expectations. I was recruited as an ethnographer for my predoctoral fellowship and was required to write fieldwork-based op-eds and analyses for my postdoctoral research fellowship. This meant that I had to adjust the presentation of my research findings for a variety of audiences: political scientists, anthropologically inclined colleagues, and nonacademics-bureaucrats, activists, and the general public. Understanding the methodological expectations of these different groups and adjusting the language of my presentation was crucial. The challenge was to strike a balance between the two styles of presentation-causality-oriented explanations for political scientists and narratives for nonpolitical-science audiences.

How best to do this? Suggestions from several scholars (LaPorte 2014; Newsome 2014; Scoggins 2014, 394-95) are worth following: readjust hypotheses, look for additional data, and triangulate the findings. Additionally, fieldwork data should be treated as evolving information emerging from respectful interactions with local interlocutors (Fujii, 2018).

I applied these strategies to my own fieldwork. Being in the field for two years before finishing my dissertation forced me to rethink and eventually decrease the number of independent variables. Ultimately, I chose to focus on two variables to explain the occurrence of local- rather than national-level accommodations of peasant interests concerning land rights and resource governance by political and economic elites.

Such a shift also happened with the $\mathrm{T}_{4} \mathrm{D}$ 's rural healthcare service research project: based on the findings that I and other ethnographers collected, my team decided to reframe the focus of our research and devised a different publication plan. Our initial plan was to write a paper to explain community members' views on and experience in two activities: (1) providing basic statistics about the state of maternal and neonatal healthcare (MNH) in their respective villages; and (2) based on these statistics, encouraging community members to promote deliberative and planning groups and formulate social-action plans to improve the quality of MNH outcomes in rural areas. However, we realized that this focus might overlook the broader, more interesting narrative: how 
ordinary community members perceive and experience development projects (including ours) based on their past experience interacting with development initiatives, actors, and agencies. After multiple discussions, we therefore decided that showing the fuller narratives from our local interlocutors-including how local history and community memories shaped their perception of the $\mathrm{T}_{4} \mathrm{D}$ project-was a better publication idea.

My experience shows that far from the glorified image of an allknowing, typically male adventurer-perhaps influenced by the masculinist hangover and the "just do it" ethos in fieldwork-based social science despite the abundance of female role models-I found that data gathering was a confusing and exhausting yet humbling experience. There were times when I had to meet with multiple interlocutors in one day, visit different government agencies to locate a key government document, and peruse the pages of dusty local-newspaper archives. When I became confused, I asked my committee members and project supervisors about the type of data that I should collect and where to find them.

This leads to the question of what counts as research foci and illuminating data for our colleagues and interlocutors, who place different emphases on the nature of the social world and their place in it. For empirical political scientists, causal claim making is probably the first priority when they make sense of their fieldwork data. However, for local interlocutors, the complexity of their experience matters more, which meant that although I paid attention to the details and nuances of my interlocutors' narratives, I ultimately had to prioritize certain accounts and leave others in my own archives.

These two different commitments are not unbridgeable. With commitment and hard work, the divide between activist and policy engagement on the one hand and theory-oriented scholarship on the other eventually can be bridged. However, navigating these different terrains without sacrificing one for the other was indeed a challenging task.

\section{ENGAGEMENT WITHIN AND OUTSIDE OF ACADEMIA}

In addition to data gathering, fieldwork can present opportunities for public engagement with academic and nonacademic audiences. In the context of Indonesia and Southeast Asia, where political science research can influence political discourses and occasionally public policies (Pepinsky 2018), these activities are worth pursuing. Moreover, these opportunities help junior researchers to build and maintain working relationships with their interlocutors, local academics, and other related stakeholders.

I have experienced this in my career. Throughout my fieldwork, I was invited to give talks in both academic and nonacademic settings, with diverse participants: academics, activists, students, and community members. This ranged from giving guest lectures at universities, research institutes, and non-governmental organizations (NGOs) to leading and organizing discussions and workshops for student activists involved in advocacy for student interests and marginalized groups (e.g., urban poor and rural peasants). From a research perspective, these invited talks allowed me to test my theories, corroborate my empirical findings, and point out missing pieces and data in my research. Such engagement is important because local research institutions and community members often have a deeper knowledge of our topics of interest (Bracic 2018, 550; Chambers-Ju 2014, 407). These invited talks and other activities also helped me to better communicate my findings to nonacademic audiences and to use my knowledge for various purposes, from providing input to mid-level bureaucrats to teaching the history of class-based social movements and research techniques for activists.

When interacting with different audiences, I also adjusted my communication style and content depending on who my counterparts were. Most of my talks might be quite similar, but I had different emphases for different audiences. For example, I felt more comfortable discussing research methodology to universitybased researchers and scholars. On other occasions, I spent more time discussing my empirical findings and their theoretical and practical implications for activists, engaged intellectuals, community members, and policy makers. Of course, this does not mean that I could not talk about methods with an activist audience or that university lecturers do not care about the practical implications of my research. The point is that different audiences have different interests in my research, and it is my responsibility to ensure that my projects address their concerns and questions and can speak to a broad audience.

For instance, whereas I support the "good fight" of my interlocutors in the agrarian movement, sometimes I have to share research findings that might be difficult for them to accept. I experienced this in 2019 when I told an audience of young scholars and activists at a week-long agrarian studies program organized by the Agrarian Resources Center-a major Indonesian research institute-about Albertus's (2015) argument that land redistribution occurs more frequently under dictatorial regimes than under democratic regimes. This argument obviously was not well received with the implicit assumption of many agrarian-justice advocates who believe that democracy provides more room for a redistributionist agenda. Of course, I presented a counterargument: a paper written by Bhattacharya, Mitra, and Ulubasoglu (2019) that argues the exact opposite of Albertus's thesis. This presentation successfully generated discussion on the future trajectory of agrarian movements among the participants and the program organizers.

These conversations, albeit difficult, should take place in any field research. Reminiscent of Scott's $(1987,202)$ experience of presenting his research findings to residents of the Malaysian village of Sedaka, my status as a researcher forces me to respond to my interlocutors in the best way possible. Conversation topics may be contentious and, as researchers, we might disagree with our interlocutors, but this should not deter from healthy, respectful discussions about our research findings and ongoing scholarly debates.

\section{A FURTHER NOTE ON REFLEXIVITY}

All of this experience eventually leads to the question of the researcher's reflexivity. Notwithstanding the pressing need for researchers to reflect on their research activities, being reflexive for political scientists conducting empirical research is still quite challenging. ${ }^{1}$ This challenge occurs partly because of the nature of empirical political science inquiry, which emphasizes empirical causation as a main goal.

However, this does not mean that any reflection is not possible. In my experience, fieldwork presents a plethora of opportunities for political scientists to think long and hard about our positionality and the implications of our work for the broader publicespecially our interlocutors-and our discipline. It forced me to think deeply about three challenging questions. 
The first, toughest question is: To what extent are we complicit in maintaining and perpetuating the pervasive state-donor-NGOresearcher industrial complex, especially in developing areas and communities? I am not defending naive moral purism, that one should avoid any engagement with state and moneyed interests. Neither am I promoting "anything goes" as long as our research projects get completed. My point is to recognize the power imbalance and societal hierarchy inherent in many elements of any social science research project. We do not have to wholly agree with Petras's (1999) assessment to understand that a large part of civil society and research activities has become increasingly more commodified and industry-like, from which researchers benefit as well (i.e., name recognition, career benefits, and opportunities to present in relatively upscale venues).

Recognizing the privileges that we accrue over time also does not mean subscribing to a postmodern skepticism of science as a totalizing and thus oppressive grand narrative. If anything, this problem of complicity begs a second question to be answered: To what extent can and have political scientists been using our fieldwork-based knowledge to deepen democracy, lessen our dependence on established interests, and work for a better society with our interlocutors? In this context, as previously discussed, research may help local interlocutors and collaborators to think about ways to promote positive social transformations.

The third more reflexive question is: How can graduate-level programs, political science departments, and the research community in general better prepare $\mathrm{PhD}$ candidates and early-career scholars to overcome difficulties during fieldwork? This question is especially pertinent considering the lack of dedicated graduatelevel qualitative-methods training in political science (Emmons and Moravscik 2020). Certainly, some research skills may be difficult to teach in a classroom setting-perhaps nothing is better than hands-on experience in building good working relationships with local interlocutors and writing grant-winning dissertation research proposals. However, as a discipline, we can do better. The first step is to recognize the complexity of field research and the market-like nature of competition for research funding. The second step is to transfer our knowledge and skills to the next generation of political scientists.

Practically speaking, this means reforming our graduate-level education so that young scholars can recognize the complexity of fieldwork logistics, the market-driven logic of fieldwork-funding competition, and ways to address these issues both personally and collectively. Some accounts detail various ways to practically navigate the logistical preparation for fieldwork and maintain continuing engagement with research counterparts and interlocutors on the field via repeated interactions (Fujii 2018; Kapiszewski, MacLean, and Read 2015). These studies can be used in graduatelevel education to stimulate further discussion on conducting fieldwork.

\section{CONCLUDING REMARKS: SUGGESTIONS FOR MOVING FORWARD}

This article delineates different modes of fieldwork and its challenges. To conclude, I propose three possible solutions to better prepare political scientists for fieldwork and its diverse experiences.

The first proposal is to promote a more honest discussion regarding fieldwork process in various avenues, from graduate- level seminars and informal departmental gatherings to conference panels and smaller workshops. These conversations are open to not only those who are oriented toward the more "traditional" qualitative fieldwork but also for those who want to integrate fieldwork with other quantitative methods, such as survey and experimental designs.

The second follow-up proposal is to provide better support for scholars in our field to conduct fieldwork. Expecting more funding to be available for field research sounds like wishful thinking in the neoliberal era; however, at the very least, political science departments can provide more training, workshops, and informal gatherings in which scholars can exchange their knowledge and skills regarding fieldwork and its logistical preparation.

It also is important to reassess and redefine our relationships with local interlocutors, particularly the subaltern ones, especially in the context of the state-donor-NGO-researcher industrial complex in fieldwork-based social science. My third proposal is a possible solution to address this problem: rather than focusing on extracting data from interlocutors merely for our career advancement-essentially a form of surplus value in the Marxian sense-and thereby widening the gap between us, perhaps we should consider other types of collaborative working possibilities, such as formulating advocacy strategies with our community partners and working on a collaborative writing project. Bleck, Dendere, and Sangaré (2018) described other examples, such as organizing research and professionalization training for young researchers from local institutions, writing op-eds with local researchers, and maintaining iterative professional interactions with local communities.

From my own experience, I reached this conclusion: after exhausting my fieldwork materials, I stopped researching agrarian politics as my main project and started thinking about ways to work together with my interlocutors. For example, I am now working collaboratively with one interlocutor-a vocational high school teacher-to write about his life history as a rural modernizer. I also participate in activist tasks, including language translation, copyediting press releases and articles, organizing solidarity campaign, and brainstorming community-organizing ideas. Finally, I chose an entirely new research topic for my next project. This type of approach to fieldwork, I believe, may help us to challenge the commodification of academic works and improve our field-research experience.

\section{ACKNOWLEDGMENTS}

I thank participants at the 2019 International Symposium of Journal Antropologi Indonesia for their constructive comments on this article. Field research for this article was made possible by generous funding from the Northern Illinois University Political Science Department Russell Smith Memorial Scholarship; Transparency for Development (T4D) Predoctoral Fellowship; ENITAS Scholarship from the Institute of Thai Studies at Chulalongkorn University; New Mandala Indonesia Correspondent Fellowship; and Japan Society for the Promotion of Science Postdoctoral Fellowship and Grant (Project No. 19F19016). Above all, I thank my local interlocutors and research colleagues for inspiring me to write this article. Any errors are solely my own.

\section{SUPPLEMENTARY MATERIALS}

To view supplementary material for this article, please visit http:// dx.doi.org/10.1017/S1049096520001663. - 


\section{NOTE}

1 In one way, perhaps it might be easier for political theorists rather than their empirical causation-oriented political science counterparts to be more reflexive because reflexivity already is inherent in their research methodology.

\section{REFERENCES}

Albertus, Michael. 2015. Autocracy and Redistribution: The Politics of Land Reform. New York: Cambridge University Press.

Aronoff, Myron J., and Jan Kubik. 2013. Anthropology and Political Science: A Convergent Approach. New York: Berghahn Books.

Bhattacharya, Prasad S., Devashish Mitra, and Mehmet A. Ulubasoglu. 2019. "The Political Economy of Land Reform Enactments: New Cross-National Evidence (1900-2010)." Journal of Development Economics 139:50-68.

Bleck, Jaimie, Chipo Dendere, and Boukary Sangaré. 2018. "Making North-South Research Collaborations Work." PS: Political Science \& Politics 51 (3): 554-58.

Bracic, Ana. 2018. "For Better Science: The Benefits of Community Engagement in Research.” PS: Political Science \& Politics 51 (3): 550-53.

Chambers-Ju, Christopher. 2014. "Data Collection, Opportunity Costs, and Problem Solving: Lessons from Field Research on Teachers' Unions in Latin America." PS: Political Science \& Politics 47 (2): 405-9.

Emmons, Cassandra V., and Andrew M. Moravscik. 2020. "Graduate Qualitative Methods Training in Political Science: A Disciplinary Crisis.” PS: Political Science \& Politics 53 (2): 258-64.

Fujii, Lee Ann. 2018. Interviewing in Social Science: A Relational Approach. New York and London: Routledge.
Hsueh, Roselyn, Francesca R. Jensenius, and Akasemi Newsome. 2014. "Fieldwork in Political Science: Encountering Challenges and Crafting.” PS: Political Science E Politics 47 (2): 391-93.

Kapiszewski, Diana, Lauren M. MacLean, and Benjamin L. Read. 2015. Field Research in Political Science: Practices and Principles. Cambridge: Cambridge University Press.

LaPorte, Jody. 2014. "Confronting a Crisis of Research Design." PS: Political Science $\mathcal{E}$ Politics 47 (2): 414-17.

Newsome, Akasemi. 2014. "Knowing When to Scale Back: Addressing Questions of Research Scope in the Field." PS: Political Science \& Politics 47 (2): 410-13.

Pepinsky, Thomas. 2018. "Everyday Political Engagement in Comparative Politics." PS: Political Science \& Politics 51 (3): 566-70.

Petras, James. 1999. "NGOs: In the Service of Imperialism." Journal of Contemporary Asia 29 (4): 429-40.

Schatz, Edward (ed.). 2009. Political Ethnography: What Immersion Contributes to the Study of Power. Chicago: University of Chicago Press.

Scoggins, Suzanne E. 2014. "Navigating Fieldwork as an Outsider: Observations from Interviewing Police Officers in China." PS: Political Science \& Politics 47 (2): 394-97.

Scott, James C. 1987. Weapons of the Weak: Everyday Forms of Peasant Resistance. New Haven, CT: Yale University Press.

Simmons, Erica S., and R. Smith Nicholas. 2019. "The Case for Comparative Ethnography." Comparative Politics 51 (3): 341-59.

Soedirgo, Jessica, and Aarie Glas. 2020. "Toward Active Reflexivity: Positionality and Practice in the Production of Knowledge.” PS: Political Science \& Politics 53 (3): 527-31. DOI:10.1017/S1049096519002233.

Yanow, Dvora, and Peregrine Schwartz-Shea. 2006. Interpretation and Method: Empirical Research Methods and the Interpretive Turn. Armonk, NY: M.E. Sharpe. 